\title{
THE EFFECT OF INTENSIVE CARE UNIT NURSES’ ANXIETY LEVELS ON
}

\section{MORAL SENSITIVITY}

\section{Yoğun Bakım Ünitesi Hemşirelerinin Anksiyete Düzeylerinin Ahlaki Duyarlılığa Etkisi}

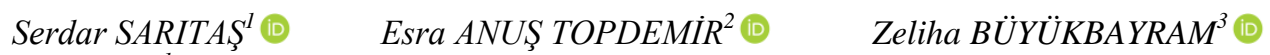 \\ ${ }^{1}$ Inonu University, Department of Surgical Nursing, Malatya, Turkey \\ ${ }^{2}$ Dicle University, Atatürk School of Health Sciences, Diyarbakir, Turkey \\ ${ }^{3}$ Siirt University, Faculty of Health, Siirt, Turkey
}

\begin{tabular}{lll}
\hline Geliş Tarihi / Received: 15.06.2020 & Kabul Tarihi / Accepted: 03.11.2020 & Yayım Tarihi /Published: 30.11 .2020 \\
\hline
\end{tabular}

\begin{abstract}
Nurses experience a great deal of stress in their work environment. This quantitative descriptive study was carried out to determine the anxiety levels and the moral sensitivity of nurses working in intensive care units. Data were collected with a personal information form, the Beck Anxiety Inventory and Moral Sensitivity Questionnaire. The data analyses were performed using descriptive statistics, independent group's t-test, the Mann-Whitney U test, the Kruskal-Wallis test and correlation analysis. It was determined that the nurses' average total Beck Anxiety Inventory score was 18.65 \pm 9.73 , average total Moral Sensitivity Questionnaire score was 96.24 \pm 24.24 . There was no relationship between anxiety and moral sensitivities of nurses ( $>>0.05)$. Research results showed that nurses had moderate levels of anxiety and moral sensitivity. With these results it may be recommended to increase in-service training to improve the moral sensitivity of intensive care nurses and to develop improvement policies to reduce their anxiety levels.
\end{abstract}

Keywords: Anxiety, Intensive Care Units, Moral Sensitivity, Nursing

\section{ÖZ}

Hemşireler, çalışma ortamlarında büyük bir stres yaşamaktadırlar. Bu nicel tanımlayıcı çalışma, yoğun bakım ünitelerinde çalışan hemşirelerin anksiyete düzeylerinin ve ahlaki duyarlılıklarının belirlenmesi amacı ile yürütüldü. Veriler; kişisel bilgi formu, Beck Anksiyete Envanteri ve Ahlaki Duyarlılık Anketi ile toplandı. Veri analizleri; tanımlayıcı istatistikler, bağımsız gruplar t-testi, Mann-Whitney U testi, Kruskal-Wallis testi ve korelasyon analizi kullanılarak yapıldı. Hemşirelerin; Beck Anksiyete Envanteri toplam puan ortalaması 18.65 \pm 9.73 , Ahlaki Duyarlılık Anketi toplam puan ortalamas1 96.24 \pm 24.24 bulundu. Hemşirelerin anksiyeteleri ve etik duyarlılıkları arasında bir ilişki yoktu $(\mathrm{p}>0.05)$. Araştırma sonuçları hemşirelerin orta düzeyde kaygı ve ahlaki duyarlılığa sahip olduğunu gösterdi. Bu sonuçlar ile yoğun bakım hemşirelerinin ahlaki duyarlılığını geliştirmek için hizmet içi eğitimin artırılması ve kaygı düzeylerini düşürmek için iyileştirme politikalarının geliştirilmesi önerilebilir.

Anahtar kelimeler: Ahlaki Duyarlılık, Anksiyete, Hemşirelik, Yoğun Bakım Üniteleri 


\section{INTRODUCTION}

Anxiety is a biological stimulus that excitatives the individual to act in order to do what is necessary in the face of a possible threat of danger. Sometimes this arises from a loss, or sometimes from an internal mental conflict. Freud explained fear as a reaction to a real threat and anxiety as a reaction to an internal danger (Bal, Çakmak, \& Uğuz, 2013).

Nurses experience a great deal of stress in their work environment because of the reasons as; differences in working conditions, inadequate control in work, increasing demands of work, lack of support, concerns about the quality of nursing care, relationships with other healthcare team members, job rotation, working systems, etc. (Aydın \& Kutlu, 2001; Lambert et al., 2004). This situation negatively affects the physiological and psychological health, social life and both individual and patient safety (Barrau-Baumstarck et al., 2009; Karagozoglu \& Bingöl, 2008). The ability of nurses to maintain their physical and mental health depends on the protection offered in their work environment from adverse physiological and societal impacts (Arcak \& Kasimoğlu, 2006). Various studies have determined the factors that nurses face in their work environment which cause stress (Kaliterna, Prizmic, \& Zganec, 2004; Lee, Hwang, Kim, \& Daly, 2004). It has been determined that long-term and frequent repetitive stressful experiences in the workplace cause social, occupational and individual problems as physical health issues, anxiety, desperation, depression, job dissatisfaction, reduced confidence related to work, reduced productivity in work, burnout syndrome, resignation, smoking, drinking, drug addiction, breakdown of family relationships, interpersonal communication problems (Paşa, 2007; Tel, Karadă̆, Aydin, \& Tel, 2003). For this reason, in order to reduce professional misconduct among nurses and improve patient safety, it is thought that positive results can be obtained in terms of performance and motivation by protecting and improving nurses' health and supporting them to overcome stress (Ören, 2011; Özgür, Yildirim, \& Aktaş, 2008)

Intensive care units support the life functions of patients' with critical health problems and special treatment is administered in them (Özgür et al., 2008). Nurses working in these units provide multidimensional, dynamic nursing care which requires attention and close observation due to busy patient circulation. Intensive care nurses, in addition to problemsolving skills in the patient care process, must use a large number of life-saving technological tools. Intensive care conditions and working conditions can affect nurses and cause various problems. When viewed from an institutional perspective, the problems encountered can hinder work performance and cause a rise in mistakes. Therefore, it may cause; economic 
losses for the institution, an increase in work accidents and a direct risk for patients care. All these factors may impact the care of the patient and cause a reduction in the quality of care (Abualrub, 2004; Arcak \& Kasimoğlu, 2006; Dunn, Wilson, \& Esterman, 2005; Oktay, 2005; Yilmaz, Hacihasanoğlu, \& Çiçek, 2006)

Ethics have become an important and systematic field of study in philosophy and science, regarding moral behaviour, actions and judgements. Ethics (ethicon, ethos) is a Greek-derived word used for manner and moral. Ethics is about doing the right thing and not doing the wrong thing (Topdal, 2012). At the same time, ethics can be defined as a group of moral principles or a set of values that direct the behavior of an individual or a profession (Bahar et al., 2011). For this reason, nurses are expected to know the basic concepts relating to; ethics, ethical principles, the ethical decision-making process and the resources that can be used in ethical dilemmas, and to comply with moral rules in an integrated approach to human (Tosun, 2005).

Moral sensitivity is an important factor in the ethical decision-making process of nurses, and is defined as the ability to distinguish ethical issues (Başak, Uzun, \& Arslan, 2010). Moral sensitivity requires an understanding of the ethical aspects of situations that concern a person's health. A critical approach, open-mindedness and courage are required for the development of moral sensitivity (Torjuul \& Sorlie, 2006). Intensive care nurses are more likely to encounter complicated and unexpected problems as a professional team member who determines changes in the patient's health and must make quick decisions in emergencies as part of a team (Eşer, Khorshid, \& Demir, 2007). A significant proportion of these problems are ethical issues. In order to be able to solve the faced ethical issues, to recognize ethical problems, and to make the best decisions, intensive care nurses' moral sensitivity must be developed. As professionals, intensive care nurses must fulfill their roles and responsibilities based on moral values. As well as contributing to their occupational professionalism, the high moral sensitivity of intensive care nurses directly influences the quality of the nursing care provided to patients (Beck, Steer, \& Carbin, 1988; Özdemir, 2007).

\section{METHOD}

\section{Design}

This quantitative descriptive research has been done to determine the effect of anxiety levels on the moral sensitivity of intensive care nurses. 


\section{Participants}

The study was carried out between April and May 2017. Research population was composed of nurses working for a training and research hospital located in South East Turkey. The total number of nurses working in intensive care units was 84. It was the intention to reach all of the nurses working in intensive care units without using any sampling method. The research was undertaken with the participation of a total of 70 nurses.

\section{Data Collection}

Data were collected by paper questionnaires (Personal Information Form, Beck Anxiety Inventory (BAI) and The Moral Sensitivity Questionnaire (MSQ)).

\section{Instruments}

\section{Personal Information Form}

The Personal Information Form consists of ten questions prepared by the researcher in accordance with the literature, concerning demographic information such as age, gender, education status, marital status and knowledge of ethics.

\section{Beck Anxiety Inventory (BAI)}

The Beck Anxiety Inventory (BAI) (Beck et al., 1988) can be used in geriatric and healthy populations, and among patients with psychiatric disorders. It measures the frequency of anxiety symptoms experienced by the individual. Individuals can answer themselves on a 4-point Likert- type self-assessment scale consisting of 21 articles scored 0-3 ("None”, "Mild" and "Severe"). The total score indicates the level of the anxiety experienced. It measures more physical symptoms of anxiety. The patients' anxiety levels are classified according to their BAI scores. A score of $0-17$ is low, 18-24 moderate and 25 or above is high. The higher score means the greater anxiety experienced. Ulusoy et al. tested the validity and reliability of the BAI with anxiety, depression, mixed, and control groups and found that it had a high internal consistency (alpha $=0.93$ ) and the total correlation of the articles ranged from 0.45 to 0.72 (Ulusoy, Sahin, \& Erkmen, 1998). The Cronbach’s Alpha coefficient of this study was found 0.82 .

\section{Moral Sensitivity Questionnaire (MSQ)}

The Moral Sensitivity Questionnaire was developed by Kim Lutzen to measure ethical sensitivity and was first used at the Karolinska Nursing Institute in 1994 (Stockholm, Sweden), primarily among physicians and nurses working in psychiatric clinics and later in 
other units. It is a 7-point Likert- type scale of 30 articles. The reliability and validity of the scale were tested by Hale Tosun in Turkey in 2003 (Tosun, 2005). The Moral Sensitivity Questionnaire is a measurement tool consisting of 30 articles in six subdimensions (Autonomy, Benefit Providing, Integrated Approach, Conflict, Application, Orientation). Articles 3, 23, and 26, were not included in Lutzen's factor analysis (Tosun, 2005). In the MSQ, the grading of statements on a scale from 1 (fully agree) to 7 (not at all) is required, 1 indicating high sensitivity to participate fully, and 7 indicating low sensitivity to not participate at all. The lowest possible score on the MSQ is 30 and the highest is 210. Low scores show high sensitivity to moral questions and high scores show low sensitivity (Tosun, 2005). The Cronbach’s Alpha coefficient of this study was found 0.87 .

\section{Data analysis}

Research data were analyzed via SPSS (Statistical Package for Social Science) 25.0 software. Whether the descriptive statistics and data on the quantitative variables were normally distributed was evaluated via Shapiro-Wilk normality test. Chi-squared tests were used to compare socio-demographic data between groups, and independent samples t-test, Mann-Whitney U, Kruskal-Wallis tests. Pearson correlation was employed for measuring the correlational power. Statistical significance was identified if the P-value was lower than 0.05 $(\mathrm{p}<0.05)$.

\section{Ethical considerations}

Before starting the study, written permissions were obtained from the Ethic Committee of Dicle University Hospitals on 17.04.2017, reference number 80, and from Diyarbakır Gazi Yaşargil Research and Training Hospital Manager on 21.04.2017, reference number 45. The criteria in the Declaration of Helsinki attached to the ethics committee's application documents were followed. The written consent of the nurses participating in the study was obtained verbally and in writing.

\section{FINDINGS}

It was determined that $81.4 \%$ of the included nurses were female, and the median age was $31.15 \pm 5.24$. It was determined that $77.1 \%$ of the nurses were married, $84.3 \%$ were university graduates, 57.1\% worked in internal medicine intensive care clinics, 78.6\% had 0-5 years' experience working in intensive care, $42.9 \%$ were partially satisfied with the unit they were working in, $55.7 \%$ were working day and night shifts, $45.7 \%$ were satisfied with the way they work, and $54.3 \%$ were educated about ethics (Table 1 ). 
Table 1. Distribution of Nurses According to Their Descriptive Characteristics $(n=70)$

\begin{tabular}{|c|c|c|}
\hline Characteristics & $\mathbf{n}$ & $\%$ \\
\hline \multicolumn{3}{|l|}{ Gender } \\
\hline Female & 57 & 81.4 \\
\hline Male & 13 & 18.6 \\
\hline \multicolumn{3}{|l|}{ Marital } \\
\hline Married & 54 & 77.1 \\
\hline Single & 16 & 22.9 \\
\hline \multicolumn{3}{|l|}{ Education level } \\
\hline High school & 9 & 12.9 \\
\hline College & 59 & 84.3 \\
\hline Postgraduate & 2 & 2.9 \\
\hline \multicolumn{3}{|l|}{ Intensive care unit } \\
\hline Internal unit & 40 & 57.1 \\
\hline Surgical unit & 30 & 42.9 \\
\hline \multicolumn{3}{|c|}{ Experience in the intensive care unit } \\
\hline $0-5$ years & 55 & 78.6 \\
\hline $6-10$ years & 15 & 21.4 \\
\hline \multicolumn{3}{|l|}{ Satisfied with the unit } \\
\hline Yes & 30 & 42.9 \\
\hline No & 22 & 31.4 \\
\hline Partially & 18 & 25.7 \\
\hline \multicolumn{3}{|l|}{ Work pattern } \\
\hline Day and night shifts & 39 & 55.7 \\
\hline Only day shifts & 31 & 44.3 \\
\hline \multicolumn{3}{|c|}{ Satisfied with the work pattern } \\
\hline Yes & 32 & 45.7 \\
\hline No & 16 & 22.9 \\
\hline Partially & 22 & 31.4 \\
\hline \multicolumn{3}{|l|}{ Educated about ethics } \\
\hline Yes & 46 & 65.7 \\
\hline No & 24 & 34.3 \\
\hline Total & 70 & 100.0 \\
\hline \multicolumn{3}{|c|}{$\begin{array}{c}\mathrm{M} \pm \mathrm{SD} \\
31.15 \pm 5.24\end{array}$} \\
\hline
\end{tabular}

It was determined that the nurses' average total BAI score was $18.65 \pm 9.73$. They scored an average total of $96.24 \pm 24.24$ for moral sensitivity and, an average score of $20.07 \pm 7.00$ for the autonomy sub-dimension, $13.00 \pm 4.90$ for the benefit sub-dimension, $14.51 \pm 5.28$ for the integrated approach sub-dimension, $13.10 \pm 3.99$ for the conflict sub- dimension, $14.10 \pm 4.98$ for the application sub-dimension, $10.14 \pm 4.99$ for the orientation sub-dimension (Table 2).

Table 2. Nurses’ Average BAI Scale Total Scores $(n=70)$

\begin{tabular}{ccccc}
\hline Scales & Total Items & Score Averages & Min. - Max & Mean \pm SD \\
\hline Total Score (BAI) & 21 & $0-63$ & $00-39$ & $18.65 \pm 9.73$ \\
\hline Autonomy & MSQ and Sub-dimension & & \\
\hline Benefit & 7 & $7-49$ & $7-39$ & $20.07 \pm 7.00$ \\
\hline Integrated approach & 4 & $4-28$ & $4-23$ & $13.00 \pm 4.90$ \\
\hline Conflict & 5 & $5-35$ & $5-29$ & $14.51 \pm 5.28$ \\
\hline Application & 3 & $3-21$ & $3-21$ & $13.10 \pm 3.99$ \\
\hline Orientation & 4 & $4-28$ & $4-23$ & $14.10 \pm 4.98$ \\
\hline Total score (MSQ) & 4 & $4-28$ & $4-24$ & $10.14 \pm 4.99$ \\
\hline
\end{tabular}


The MSQ scores for orientation sub-dimension were statistically significant $(\mathrm{p}<0.05)$ for marital status. MSQ scores for autonomy sub-dimension were statistically significant $(\mathrm{p}<0.05)$. The difference between the overall satisfaction with the work unit, and the mean scores of MSQ total, application and orientation sub-dimensions was found to be significant $(\mathrm{p}<0.05)$.

The BAI and MSQ scores were statistically insignificant ( $>>0.05$ ) for gender, marital status, education, intensive care unit experience in intensive care unit, work pattern, satisfaction with the work pattern, and education in ethics. The difference between these groups mean score was found to be statistically insignificant ( $>>0.05$ ) (Table 3). 
Table 3. Comparison of the Descriptive Characteristics of Nurses' Average BAI and MSQ Scores ( $\mathrm{n}=70)$

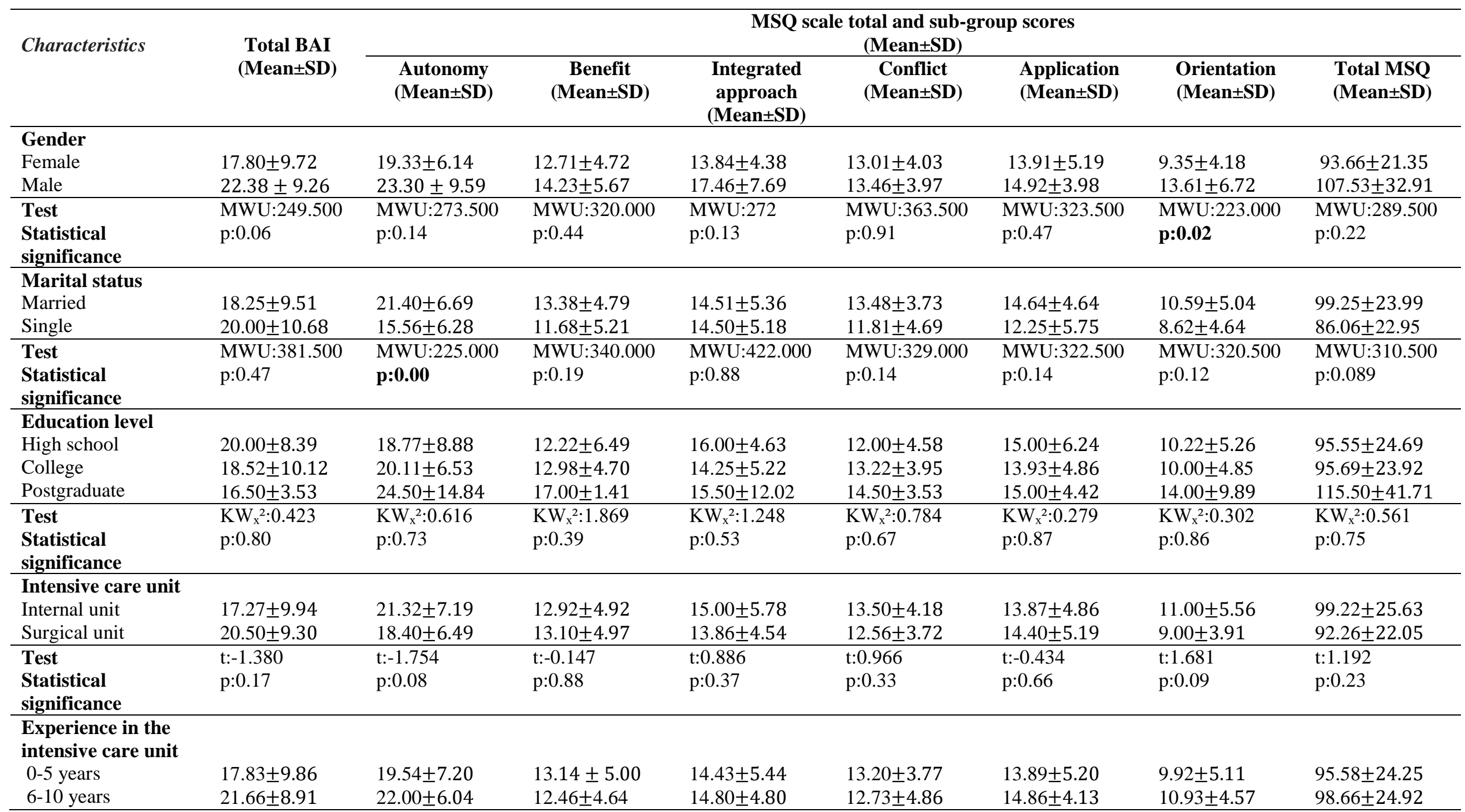


Serdar SARITAS, Esra ANUS TOPDEMIR, Zeliha BÜYÜKBAYRAM

\begin{tabular}{|c|c|c|c|c|c|c|c|c|}
\hline $\begin{array}{l}\text { Test } \\
\text { Statistical } \\
\text { significance }\end{array}$ & $\begin{array}{l}\text { MWU:321.500 } \\
\text { p:0.19 }\end{array}$ & $\begin{array}{l}\text { MWU:329.500 } \\
\text { p:0.23 }\end{array}$ & $\begin{array}{l}\text { MWU:385.500 } \\
\text { p:0.69 }\end{array}$ & $\begin{array}{l}\text { MWU:390.000 } \\
\text { p:0.74 }\end{array}$ & $\begin{array}{l}\text { MWU:389.000 } \\
\text { p:0.73 }\end{array}$ & $\begin{array}{l}\text { MWU:362.000 } \\
\text { p:0.46 }\end{array}$ & $\begin{array}{l}\text { MWU:324.500 } \\
\text { p:0.20 }\end{array}$ & $\begin{array}{l}\text { MWU:382.000 } \\
\text { p:0.66 }\end{array}$ \\
\hline \multicolumn{9}{|l|}{$\begin{array}{l}\text { Satisfied with the } \\
\text { unit }\end{array}$} \\
\hline Yes & $17.36 \pm 9.55$ & $19.23 \pm 7.31$ & $12.06 \pm 5.11$ & $14.40 \pm 5.61$ & $13.00 \pm 3.99$ & $13.50 \pm 5.24$ & $9.26 \pm 4.91$ & $92.76 \pm 24.65$ \\
\hline No & $20.18 \pm 10.35$ & $18.59 \pm 5.85$ & $12.59 \pm 4.40$ & $13.04 \pm 3.92$ & $12.86 \pm 3.64$ & $12.31 \pm 4.58$ & $8.45 \pm 3.06$ & $88.40 \pm 16.75$ \\
\hline Partially & $18.94 \pm 9.53$ & $23.27 \pm 7.11$ & $15.05 \pm 4.78$ & $16.50 \pm 5.79$ & $13.55 \pm 4.57$ & $17.27 \pm 3.52$ & $13.66 \pm 5.48$ & $111.61 \pm 25.03$ \\
\hline $\begin{array}{l}\text { Test } \\
\text { Statistical } \\
\text { significance } \\
\end{array}$ & $\begin{array}{l}\mathrm{KW}_{\mathrm{x}}{ }^{2}: 1.419 \\
\mathrm{p}: 0.49\end{array}$ & $\begin{array}{l}\mathrm{KW}_{\mathrm{x}}^{2}: 5.073 \\
\mathrm{p}: 0.07\end{array}$ & $\begin{array}{l}\mathrm{KW}_{\mathrm{x}}^{2}: 4.146 \\
\mathrm{p}: 0.12\end{array}$ & $\begin{array}{l}\mathrm{KW}_{\mathrm{x}}^{2}: 3.437 \\
\mathrm{p}: 0.17\end{array}$ & $\begin{array}{l}\mathrm{KW}_{\mathrm{x}}^{2}: 0.457 \\
\mathrm{p}: 0.796\end{array}$ & $\begin{array}{l}\mathrm{KW}_{\mathrm{x}}^{2}: 10.623 \\
\mathbf{p}: \mathbf{0 . 0 0}\end{array}$ & $\begin{array}{l}\mathrm{KW}_{\mathrm{x}}^{2}: 12.247 \\
\mathbf{p}: \mathbf{0 . 0 0}\end{array}$ & $\begin{array}{l}\mathrm{KW}_{\mathrm{x}}^{2}: 9.269 \\
\text { p:0.01 }\end{array}$ \\
\hline \multicolumn{9}{|l|}{ Work pattern } \\
\hline Day and night shifts & $18.84 \pm 9.78$ & $20.41 \pm 7.25$ & $13.10 \pm 5.01$ & $14.64 \pm 5.55$ & $13.66 \pm 4.02$ & $14.74 \pm 5.10$ & $9.84 \pm 5.30$ & $97.71 \pm 24.86$ \\
\hline Only day shifts & $18.41 \pm 9.84$ & $19.64 \pm 6.78$ & $12.87 \pm 4.84$ & $14.35 \pm 5.01$ & $12.38 \pm 3.90$ & $13.29 \pm 4.78$ & $10.51 \pm 4.62$ & $94.38 \pm 23.72$ \\
\hline Test & $\mathrm{t}: 0.181$ & $\mathrm{t}: 0.451$ & $\mathrm{t}: 0.195$ & $\mathrm{t}: 0.223$ & $\mathrm{t}: 1.338$ & $\mathrm{t}: 1.217$ & $\mathrm{t}:-0.555$ & $\mathrm{t}: 0.568$ \\
\hline $\begin{array}{l}\text { Statistical } \\
\text { significance }\end{array}$ & p:0.85 & p:0.65 & p:0.84 & p:0.82 & p:0.18 & p:0.22 & p:0.58 & p:0.57 \\
\hline \multicolumn{9}{|l|}{$\begin{array}{l}\text { Satisfied with the } \\
\text { work pattern }\end{array}$} \\
\hline Yes & $18.78 \pm 9.14$ & $19.18 \pm 8.12$ & $12.00 \pm 5.11$ & $13.93 \pm 5.63$ & $12.71 \pm 3.87$ & $13.50 \pm 5.04$ & $9.62 \pm 5.29$ & $92.28 \pm 26.92$ \\
\hline No & $19.56 \pm 10.97$ & $21.06 \pm 6.58$ & $14.12 \pm 5.01$ & $16.43 \pm 4.87$ & $12.75 \pm 3.43$ & $14.12 \pm 4.70$ & $11.43 \pm 3.61$ & $99.87 \pm 19.73$ \\
\hline Partially & $17.81 \pm 10.03$ & $20.63 \pm 5.51$ & $13.63 \pm 4.43$ & $13.95 \pm 4.93$ & $13.90 \pm 4.57$ & $14.95 \pm 5.18$ & $9.95 \pm 5.42$ & $99.36 \pm 23.22$ \\
\hline Test & $\mathrm{KW}_{\mathrm{x}}^{2}: 0.830$ & $\mathrm{KW}_{\mathrm{x}}^{2}: 2.630$ & $\mathrm{KW}_{\mathrm{x}}^{2}: 1.952$ & $\mathrm{KW}_{\mathrm{x}}^{2}: 2.421$ & $\mathrm{KW}_{\mathrm{x}}^{2}: 3.823$ & $\mathrm{KW}_{\mathrm{x}}^{2}: 1.850$ & $\mathrm{KW}_{\mathrm{x}}^{2}: 0.965$ & $\mathrm{KW}_{\mathrm{x}}^{2}: 3.724$ \\
\hline $\begin{array}{l}\text { Statistical } \\
\text { significance }\end{array}$ & p:0.66 & $\mathrm{p}: 0.26$ & $\mathrm{p}: 0.37$ & p:0.29 & $\mathrm{p}: 0.14$ & $\mathrm{p}: 0.39$ & $\mathrm{p}: 0.61$ & p:0.15 \\
\hline \multicolumn{9}{|l|}{$\begin{array}{l}\text { Educated about } \\
\text { ethics }\end{array}$} \\
\hline Yes & $17.32 \pm 9.84$ & $19.95 \pm 6.95$ & $12.52 \pm 5.06$ & $14.82 \pm 5.69$ & $12.52 \pm 4.07$ & $13.93 \pm 5.17$ & $10.45 \pm 5.51$ & $95.58 \pm 26.02$ \\
\hline No & $21.20 \pm 9.20$ & $20.29 \pm 7.24$ & $13.91 \pm 4.55$ & $13.91 \pm 4.45$ & $14.20 \pm 3.67$ & $14.41 \pm 4.68$ & $9.54 \pm 3.82$ & $97.50 \pm 20.88$ \\
\hline $\begin{array}{l}\text { Test Statistical } \\
\text { significance }\end{array}$ & $\begin{array}{l}\mathrm{t}:-1.601 \\
\mathrm{p}: 0.11\end{array}$ & $\begin{array}{l}\mathrm{t}:-0.189 \\
\mathrm{p}: 0.85\end{array}$ & $\begin{array}{l}\mathrm{t}:-1.131 \\
\mathrm{p}: 0.26\end{array}$ & $\begin{array}{l}\mathrm{t}: 0.681 \\
\mathrm{p}: 0.49\end{array}$ & $\begin{array}{l}\text { t:-1.699 } \\
\mathrm{p}: 0.09\end{array}$ & $\begin{array}{l}\text { t:-0.382 } \\
\mathrm{p}: 0.70\end{array}$ & $\begin{array}{l}\mathrm{t}: 0.725 \\
\mathrm{p}: 0.47\end{array}$ & $\begin{array}{l}\text { t:-0.311 } \\
\text { p:0.74 }\end{array}$ \\
\hline
\end{tabular}


There was no relationship between anxiety and MSQ total and sub-group scores ( $>0.05)$ (Table 4).

Table 4. Analysis of the Statistical Associations Between the Mean of Nurses' BAI Scores and Means of Their MSQ and MSQ Sub-scale Scores $(\mathrm{n}=70)$

\begin{tabular}{cccccccc}
\hline $\begin{array}{c}\text { MSQ and } \\
\text { Sub-dimension }\end{array}$ & Autonomy & Benefit & $\begin{array}{c}\text { Integrated } \\
\text { approach }\end{array}$ & Conflict & Application & Orientation & $\begin{array}{c}\text { Total } \\
\text { score } \\
\text { MSQ }\end{array}$ \\
\hline BAI & $\mathrm{r}=0.90$ & $\mathrm{r}=0.10$ & $\mathrm{r}=0.88$ & $\mathrm{r}=0.91$ & $\mathrm{r}=0.14$ & $\mathrm{r}=-0.34$ & $\mathrm{r}=0.70$ \\
& $\mathrm{p}=0.45$ & $\mathrm{p}=0.93$ & $\mathrm{p}=0.46$ & $\mathrm{p}=0.45$ & $\mathrm{p}=0.24$ & $\mathrm{p}=0.77$ & $\mathrm{p}=0.56$ \\
\hline
\end{tabular}

\section{DISCUSSION}

BAI scores of 0-17 are low, 18-24 moderate, and 25 or above are high, 30 is the lowest MSQ score and 210 is the highest (Öner, 2012; Tosun, 2005).

Our study has found that the average total BAI and total MSQ scores were moderate (Table 2). In a study conducted to determine the anxiety levels of 622 nurses working in various health-care facilities, state and continuous anxiety scores were identified to be moderate, similar to our results (Durmuş \& Günay, 2007). The findings of Başak and et al.'s study on intensive care nurses' ethical sensitivity are moderately similar to ours (Başak et al., 2010). Tosun's study on 170 nurses, seeking descriptive- relationships, found nurses working in psychiatric clinics to have moderate ethical sensitivity (Tosun, 2005). Tazegün and et al. determined that pediatric nurses' moral sensitivity was moderate, similar to the present study (Tazegün \& Çelebioğlu, 2016). In Arslan’s study, the moral sensitivity in the intensive care nurses was determined moderate (Arslan, 2017; Daşbilek, 2016).

The MSQ orientation sub-dimension of the nurses was statistically significant in the term of sex (Table 3). Tazegün and Çelebioğlu did not find a significant difference in the level of moral sensitivity between genders among nurses (Tazegün \& Çelebioğlu, 2016). In contrast to this result, in a meta-analysis of the impact of gender differences on the level of moral sensitivity, it was determined that women had higher sensitivity than men (You, Maeda, \& Bebeau, 2011). It can be considered that the statistical significance between sexes on the MSQ orientation sub-dimension in our study was due to the low number of male nurses participating. It can be said that the lack of male nurses is the result of the fact that nursing education in Turkey has only been opened to men in 2007.

The autonomic sub-dimension of the nurses was determined to be statistically significant by marital status (Table 3 ). In the literature there is no significant difference between marital status and sensitivity (Başak et al., 2010; Ersoy \& Göz, 2001). Tosun, found that scores on the sub-dimension of benefit were higher in married nurses than in bachelors 
(Tosun, 2005). It can be said that the responsibility brought by marriage positively influences the autonomy sub-dimension.

In this study, there is no relationship between nurses' anxiety and moral sensitivity. There is no study in the literature that shows this relationship. However, different results may occur with new researches after the covid-19 pandemic.

\section{Limitations}

The results of the study can be generalized only to this sample group. A study with a larger sample could facilitate the generalization of results.

\section{Clinical Implications and Future Directions}

This research determined that the average total BAI and MSQ scores were moderate. The relationship between anxiety and moral sensitivity was not determined. Future studies aiming to improve the moral sensitivity of intensive care nurses may seek to identify and solve ethical problems. The anxiety levels of nurses working in intensive care units could be examined periodically and larger samples would allow researchers to determine the moral sensitivity of intensive care nurses and the different variables that influence anxiety.

\section{Conflict of interest}

The authors declare that there is no conflict of interest.

\section{Funding}

This research received no specific grant from any funding agency in the public, commercial, or not-for-profit sectors.

\section{Acknowledgements}

The authors would like to thank the nurses who participated in the study.

\section{REFERENCES}

Abualrub, R. F. (2004). Job stress, job performance, and social support among hospital nurses. Journal of Nursing Scholarship: An Official Publication of Sigma Theta Tau International Honor Society of Nursing, 36(1), 73-78. https://doi.org/10.1111/j.1547-5069.2004.04016.x

Arcak, R., Kasimoğlu, E. (2006). Diyarbakır merkezdeki hastane ve sağlık ocaklarında çalışan hemşirelerin sağllk hizmetlerindeki rolü ve iş memnuniyetleri. Dicle Tıp Dergisi, 33(1), 23-30.

Arslan, G., (2017). Hemşirelerin Etik Duyarlılık Düzeylerinin Yoğun Bakıma Özel Etik Konulardaki Yaklaşımları Üzerine Etkisi. Yayınlanmamış Yüksek Lisans Tezi. Acıbadem Mehmet Ali Aydınlar Üniversitesi/Sağllk Bilimler Enstitüsü, İstanbul. 
Aydın, R., Kutlu, F. (2012). Hemşirelerde iş doyumu ve kişilerarası çatışma eğilimi ile ilgili değişkenler ve iş doyumunun çatı̧̧ma eğilimi ile olan iliş̧kisini belirleme. Cumhuriyet Üniversitesi Hemşirelik Yüksekokulu Dergisi 5(2), 37-45.

Bahar, Z., Beşer, A., Mizrak, B., Bahçelioğlu, D., Demirtaş, D., Özdemir, D., ... Elcigil, A. (2011). Hemşirelerin Karşılaştıkları Etik İkilemlerin İncelenmesi. Anadolu Hemşirelik ve Sağllk Bilimleri Dergisi, 14(2), 5260.

Bal, U., Çakmak, S., Uğuz, Ş. (2013). Anksiyete Bozukluklarında Cinsiyete Göre Semptom Farkllliklarl. Arşiv Kaynak Tarama Dergisi, 22(4), 441-459.

Barrau-Baumstarck, K., Rebeschini, E., Dalivoust, G., Durand-Bruguerolle, D., Gazazian, G., Martin, F. (2009). [Shiftwork and quality of life among critical care nurses and paramedical personnel]. Presse Medicale (Paris, France: 1983), 38(3), 346-353. https://doi.org/10.1016/j.lpm.2008.06.018.

Başak, T., Uzun, Ş., Arslan, F. (2010). Yoğun bakım hemşirelerinin etik duyarlllıklarının incelenmesi. Investigation of the moral sensibility of intensive care nurses., 52(2), 76-81.

Beck, A. T., Steer, R. A., Carbin, M. G. (1988). Psychometric properties of the Beck Depression Inventory: Twenty-five years of evaluation. Clinical Psychology Review, 8(1), 77-100. https://doi.org/10.1016/02727358(88)90050-5.

Daşbilek, F., (2016). Hemşirelerin Kişsisel Değerleri İle Etik Duyarlılıklarının Bazı Değişsenler Açısından İncelenmesi, Yayınlanmamış Yüksek Lisans Tezi. Atatürk Üniversitesi/Sağllk Bilimler Enstitüsü, Erzurum.

Dunn, S., Wilson, B., Esterman, A. (2005). Perceptions of working as a nurse in an acute care setting. Journal of Nursing Management, 13(1), 22-31. https://doi.org/10.1111/j.1365-2834.2004.00452.x.

Durmuş, S., Günay, O. (2007). Hemşirelerde iş doyumu ve anksiyete düzeyini etkileyen faktörler. Erciyes Tip Dergisi 29(2), 139-146.

Ersoy, N., Göz, F. (2001). The ethical sensitivity of nurses in Turkey. Nursing Ethics, 8(4), 299-312. https://doi.org/10.1177/096973300100800403.

Eșer. I., Khorshid, L., Demir Y., (2007). Yoğun bakım hemşirelerinde eleştirel düşünme eğilimi ve etkileyen faktörlerin incelenmesi. Cumhuriyet Üniversitesi Hemșirelik Yüksekokulu Dergisi 11, 13-22.

Kaliterna, L. L., Prizmic, L. Z., Zganec, N. (2004). Quality of life, life satisfaction and happiness in shift- and non-shiftworkers. Revista de Saúde Pública, 38, 3-10. https://doi.org/10.1590/S003489102004000700002

Karagozoglu, S., Bingöl, N. (2008). Sleep quality and job satisfaction of Turkish nurses. Nursing Outlook, 56(6), 298-307.e3. https://doi.org/10.1016/j.outlook.2008.03.009.

Lambert, V. A., Lambert, C. E., Itano, J., Inouye, J., Kim, S., Kuniviktikul, W., ... Ito, M. (2004). Cross-cultural comparison of workplace stressors, ways of coping and demographic characteristics as predictors of physical and mental health among hospital nurses in Japan, Thailand, South Korea and the USA (Hawaii). International Journal of Nursing Studies, 41(6), 671-684. https://doi.org/10.1016/j.ijnurstu.2004.02.003.

Lee, H., Hwang, S., Kim, J., Daly, B. (2004). Predictors of life satisfaction of Korean nurses. Journal of Advanced Nursing, 48(6), 632-641. https://doi.org/10.1111/j.1365-2648.2004.03251.x.

Oktay, M., (2005). Çalışma yaşamında iş yerinde stres. İbrahim Balcıŏglu (Ed.) Medikal Açıldan Stres ve Çareleri. İstanbul Üniversitesi/Cerrahpașa Tip Fakültesi Sürekli Tıp Eğitimi Etkinlikleri Sempozyum Dizisi, İstanbul, 47, 111-116.

Öner, A., (2012). Yetişkin Bireylerin Anksiyete Bozukluğuna Sahip Olup Olmaması ile Kullandıkları Mizah Tarzlarl Arasındaki İlişkinin Incelenmesi. Yayınlanmamış Yüksek Lisans Tezi. Çukurova Üniversitesi/Sosyal Bilimler Enstitüsü, Adana. 
Ören, B. (2011). Yoğun Bakımlarda Hasta ve Çalışan Stresi. Yoğun Bakım Hemşireliği Dergisi, 15(1), 29-35.

Özdemir, L., (2007). Hafif Alzheimer Hastalarına Uygulanan Çoklu Duyusal Uyaran Yönteminin Kognitif Durum, Depresyon ve Anksiyete Üzerine Etkisi. Yayınlanmamış Doktora Tezi. Hacettepe Üniversitesi/Săglık Bilimleri Enstitüsü, Ankara.

Özgür, G., Yildirim, S., Aktaș, N. (2008). Bir Üniversite Hastanesinin Ameliyathane ve Yoğun Bakım hemşirelerinde Ruhsal Durum Değerlendirmesi. Cumhuriyet Üniversitesi Hemşirelik Yüksekokulu Dergisi 12(2).

Paşa M., (2007). Stresin bireysel performans üzerindeki etkileri ve bir uygulama. Yayınlanmamış Doktora tezi. Uludă̆ Üniversitesi/Sosyal Bilimler Enstütüsü, Bursa.

Tazegün, A., Çelebioğlu, A. (2016). Çocuk hemşirelerinin etik duyarlılık düzeyleri ve etkileyen faktörler. İzmir Dr. Behçet Uz Çocuk Hastanesi Dergisi, 6(2), 97-102.

Tel, H., Karadağ, M., Aydin, Ş., Tel, H. (2003). Sağlık Çalışanlarının Çalışma Ortamındaki Stres Yaşantıları İle Başetme Durumlarının Belirlenmesi. Hemşirelikte Araştırma Geliştirme Dergisi, 5(2), 13-23.

Topdal, B., (2012). Yönetici Hemşirelerde Etik Davranışlar. Yayınlanmamış Yüksek Lisans Tezi. Beykent Üniversitesi/Sosyal Bilimler Enstitüsü İsletme Anabilim Dall, İstanbul.

Torjuul, K., Sorlie, V. (2006). Nursing is different than medicine: Ethical difficulties in the process of care in surgical units. Journal of Advanced Nursing, 56(4), 404-413. https://doi.org/10.1111/j.13652648.2006.04013.x.

Tosun, H., (2005). Sağlık Bakım Uygulamalarında Deneyimlenen Etik İkilemlere Karşı Hekim ve Hemşirelerin Duyarlılıklarının Belirlenmesi. Yayınlanmamış Doktora Tezi. İstanbul Üniversitesi/Sağlık Bilimleri Enstitüsü, İstanbul.

Ulusoy, M., Sahın, N., Erkmen, H. (1998). Turkish version of the Beck Anxiety Inventory: Psychometric Properties. Journal of Cognitive Psychotherapy, https://baskent.elsevierpure.com/tr/publications/turkish-version-of- $\quad$ the-beck-anxiety-inventorypsychometric-proper.

Yılmaz, S., Hacihasanoğlu, R., Çiçek, Z. (2006). Hemşirelerin genel ruhsal durumlarının incelenmesi. STED/Sürekli Tıp Ĕ̈itimi Dergisi, 15(6), 92-97.

You, D., Maeda, Y., Bebeau, M. J. (2011). Gender Differences in Moral Sensitivity: A Meta-Analysis. Ethics \& Behavior, 21(4), 263-282. https://doi.org/10.1080/10508422.2011.585591. 